\title{
茨城県南部の病院に勤務する看護婦の ライフスタイルと社会・心理的要因との関連性
}

\author{
鈴 木 みずえ*1・柏木とき江*2 \\ 山田 紀代美*3 ・佐 藤 和佳子*4
}

A Study on Life Style and Psychosocial Factors
of Nurses Working at Hospitals
in the Sourthern Part of Ibaraki Prefecture, Japan

\author{
Mizue SUZUKI*1, Tokie KASIWAGI*2 \\ Kiyomi YAMADA*3, Wakako SATOU*4 \\ ${ }^{* 1}$ School of Nursing, Hamamatsu University \\ *2 Department of Nursing, Tsukuba Memorial Hospital \\ *3 Hamamatsu College, University of Shizuoka \\ *4 Department of Nursing, University of Yamagata School of Medicine
}

\begin{abstract}
Abstact
We conducted a study on 1,150 nurses working at hospitals in the southern port of Ibaraki prefecture, Japan to clarify the relationship between psychosocial factors and life style among nurses working hospitals in southern port of Ibaraki prefecture, Japan.

The following results were obtained:

1. The average Health practice index (HPI) was $4.8 \pm 1.29$ (means \pm SD). The average HPI of the age group 50 and over was higher than that of the other groups.

2. According to the data of all the subjects together, Health practice index (HPI) was significantly related to the General Health Questionnaire (GHQ), work-life satisfaction and life satisfaction. 3 . In the age group 20-29 and 30-39, HPI was positively correlated with the work-life satisfaction and life satisfaction, but negatively correlated with General Health Questionnaire (GHQ).

4. In the age group 40-49, negative correlation of Health practice index (HPI) with General Health Questionnaire (GHQ) was observed while a positive correlation of Health practice index (HPI) and social supports was observed in the age group 50 and over.
\end{abstract}

\section{要旨}

看護婦のライフスタイルと社会・心理的要因などの関係を明かにするために，茨城県南 部の100床以上の病院に勤務する看護婦 1,150 名を対象に調査を実施した。

(1) ライフスタイル得点であるHPI の平均は $4.8 \pm 1.29$ であり, 年齢毎に増加する傾向が 認められた。

(2) 全対象者においてライフスタイルに有意な相関関係があるのは, 精神健康度, 働きが 
い度, 生活満足度であった。

(3) 年齢階級別に検討すると, 20 歳代, 30歳代のライフスタイルは働きがい度, 生活満足 度と正の相関, 精神健康度と負の相関が有意 $(\mathrm{p}<0.01)$ 飞認められた。40歳代では, ラ イフスタイルと精神健康度は有意な負の相関, 50歳代ではライフスタイルと社会的支援 に正の相関が有意 $(\mathrm{p}<0.05)$ に認められた。

\section{I . 緒言}

看護職者は，その業務上の特性から複雑な対 人関係や不規則な勤務労働が多く，精神的，身 体的ストレスが激しいことは従来から指摘され ている ${ }^{1 \sim 4)}$ 。急速な高齢化社会による看護職不 足から看護職者の労働条件の改善策が進められ ているが，現状としては未だに厳しい問題も残 されている。

現在, 予防医学および公衆衛生学における学 働者の健康状況に関する研究は, 労働者の労働 条件と健康度あるいは労働者のライフスタイル (生活習慣)と身体拈よび精神的な健康度の関連 について研究が進められている5 9)。その結果, 健康度はライフスタイル拉よびQOLを関連づ けて評価する必要があると言われている ${ }^{5 \sim 9) 。 ~}$ 看護職者については厳しい条件にあっても，よ り高い労働生活の質 “Quality of Working Life” 8) を目指し，健康的なライフスタイルを保ち，長 く職務を継続できることが望ましい。しかしな がら, 看護婦のライフスタイルに関する研究は 現在ほとんどみられない。

本研究では, ライフスタイルと包括的な労働 生活満足度である働さがい度, 主観的なQOL, 精神健康度などの社会・心理的要因の関係を年 齢別に明らかにすることを目的とする。

\section{II. 対象および方法}

茨城県内の地域医療を中心的に担う公立ある いは私立100床以上の病院10力所に拈いて, 常 勤の看護婦扔よび准看護婦を対象にした。看護 職はその大半が女性であることから，本調査に おいては女性のみを対象にした。また，看護学 生拈よびパート勤務者も除いた。調査期間は平 成 4 年 12 月 平成 5 年 1 月, 10 病院の対象者に 無記名式質問紙調查を実施した。対象者 1,411
人に調査の説明および調査票を同封して依頼し た。回収されたのは 1,275 人(回収率 $90.4 \%$ ), その内, 無記入多数の回答は無効とし, すべて の項目に回答の得られた 1,150 人 (平均年齢 30.70 土8.42歳)を有効回答とした(有効回答率 $81.5 \%$ )。

調査項目は以下の項目からなる。

1 ) 基本的属性 : 年齢, 臨床経験年数, 家族状 況, 居住形態, 勤務形態, 1 力月の夜勤回数な どを質問した。

2 ) ライフスタイル得点Health Practice Index (以後HPI ${ }^{5,7,8)}$ : ライフスタイルについてはBelloc $5^{10)}$, Berkman $5^{9)}$ は健康状況や死亡率を決 定する要因としてライフスタイルを研究してい る。わが国では森本ら ${ }^{5 \sim 7)}$ がライフスタイル に関する研究を行っており, ライフスタイルと 健康度や遺伝子レベルの関連についての報告を している。本研究では, Breslow ${ }^{9,10)}$ のライフ スタイル尺度の改訂版であり, わが国の生活習 慣に合わせて妥当性, 信頼性の検討された森本 の 8 つの生活習慣 ${ }^{8}$ （運動, 飲酒, 哭煙, 睡眠 時間, 朝食, 栄養バランス, 労働時間, 自覚的 ストレス５，6）を用いた。Breslowら 10,11) はラ イフスタイルを主観的な健康度評価を含めた生 活習慣として招り, 森本, 丸山ら5,8) も労働者 に対しては自覚的ストレス度を用いていており, 本研究においては森本の尺度 ${ }^{8)}$ を採用した。こ れは理想的な回答を(1)，その他を(0)として合 計して括り, 最高得点 8 , 最低得点 0 点である。 3) 精神健康度: 精神の健康状態については Goldberg ${ }^{12)}$ により作成され中川ら ${ }^{13)}$ によって 妥当性, 信頼性の検証された日本語版General Health Questionnaire (以後GHQ) にGHQの短 縮版28項目を用いた。一般労働者の調査では, ライフスタイルと精神および身体の健康の関連 があるとの報告されており8), 本研究では, 信 頼性, 妥当性のある本尺度を用いた。精神的健 
康採点には 4 段階を 2 分肢で 0 点か 1 点で採点 するGHQ法による得点を行い，精神健康度の 最も悪化状況を示す最高得点 28 点から良好な状 況を示す最低得点 0 点となる。

4) 働きがい度(Work-Life Satisfaction), 生 活満足度 (Life Satisfaction)：働きがい度は労 働者として仕事に関する満足度の指標である丸 山ら ${ }^{8)}$ とって妥当性, 信頼性の検証された動 きがい度に関する評価尺度を用いた。「家庭の 雲囲気」, 「仕事の満足度」, 「職場の雲囲気」, 「職場の人間関係」,「余暇時間の利用」,「将来 に対する希望」の 6 項目から構成されており, $\lceil 大$ 変良い(満足)」に 3 点,「かなり良い(満足)」 に 2 点,「少し良い(満足)」に 1 点,「いいえ」 に0点を与え，それぞれの項目で合計した(最 高得点18点, 最低得点0点)。

5 ) 生活満足度 (Life Satisfaction) は個人の主 観的QOLを問らために「毎日の生活に満足して いますか」と言う直接的な質問を 1 項目行い, 働きがい度と同様に採点した ${ }^{8)}$ 。この尺度は, 1 項目だけであるが，人々の生活の質を主観的 側面から測定しており, 信頼性, 妥当性を十分 備えているため，QOLの調査 ${ }^{14,15)}$ などで使用 されている。

6 ) 社会的支援 (Social Support)：社会的支援 は，精神的ストレスなどとの関連も指摘されて いることから本研究に加えた。ここでは友人, 親戚, 同僚之の関係について妥当性, 信頼性の ある尺度を用いた(最高得点 4 点, 最低得点 0 点) ${ }^{3)}$ 。

なお, 各項目の得点はGHQ以外は高い汪ど 良好な状況をを示している。関連の指標として， ピアソンの相関係数 $\mathrm{r}$ を用いた。各項目の得点 は離散量であるが, 各項目において構成得点数
が多いため，正規分布に近似し，それを用いて 信頼区間を求めた。有意水準については, HPI を中心として考慮し，20歳代拈よび30歳代では 有意水準 $1 \%$ としたが，これに対して40歳代お よび50歳代では対象者の数が著しく減少するこ とから有意水準 $1 \%$ では対象者の不足による検 出力の不足が生じてしまう。そこで，40歳代拉 よび50歳代では有意水準の検出力を上げるため に有意水準 $5 \%$ で算出した。HPI とそれぞれの 要因との相関行列と同時に相関関係を示す図を 対応して作成した。解析には統計解析ソフトウェ アSAS(Statistical Analysis System)を使用し た。

\section{III. 結果}

表 1 は年齢階級別のライフスタイル得点(HPI), $\mathrm{GHQ}$, 働きがい度, 夜勤回数の平均を示した。 HPI の全対象者の平均は $4.78 \pm 1.29$, 年齢別で は20代が最も低く $4.61 \pm 1.23,50$ 歳代が $5.14 \pm$ 1.13 年齢によって増加する傾向がみられた。 $\mathrm{QHQ}$ の全対象者の平均は $10.13 \pm 6.0$, 最も良 好な状況を示したのは50歳代で5.14, 最も不良 な状況を示したのは30歳代で10.52であった。 働きがい度の全対象者の平均は6.49土2.74であ り, 年齢別では, HPI と同様に年齢によって増 加する傾向がみられた。夜勤回数は全体対象者 では6.68 \pm 3.48 , 最も回数の多いのは 20 歳代の 7.63 , 年齢階級進むにつれ減少していた。

表 2 は20歳代の各項目の相関行列を示した。 夜勤回数については, 看護業務上特徵的な勤務 体制でもあり, 本研究において検討している各 要因について関連が予測され, 要因のひとつと して検討した。HPI とGHQは負の相関, HPI と 働きがい度, 生活満足度とは正の有意な相関を

Table 1 The Distributions of Health Practice Index (HPI) , The 28-items General Health Questionnaire (GHQ) and Work-Life Satisfaction by the age groups

\begin{tabular}{ccccc}
\hline Age (Years) & $\begin{array}{c}\text { Health Practice } \\
\text { Index (HPI) } \\
(\text { mean } \pm \text { SD })\end{array}$ & $\begin{array}{c}\text { The 28-items } \\
\text { GHQ } \\
(\text { mean } \pm \text { SD })\end{array}$ & $\begin{array}{c}\text { Work-Life } \\
\text { Satisfaction } \\
(\text { mean } \pm \text { SD) }\end{array}$ & $\begin{array}{c}\text { Number of } \\
\text { Night Shift } \\
\text { mean } \pm \text { SD) }\end{array}$ \\
\hline $20-29(\mathrm{n}=639)$ & $4.61 \pm 1.23$ & $10.40 \pm 6.00$ & $6.59 \pm 2.77$ & $7.63 \pm 2.98$ \\
$30-39(\mathrm{n}=308)$ & $4.93 \pm 1.35$ & $10.52 \pm 6.11$ & $6.01 \pm 2.54$ & $5.71 \pm 3.73$ \\
$40-49(\mathrm{n}=161)$ & $5.07 \pm 1.37$ & $8.68 \pm 5.63$ & $6.69 \pm 2.70$ & $5.38 \pm 3.44$ \\
$50-\quad(\mathrm{n}=42)$ & $5.14 \pm 1.14$ & $8.60 \pm 6.14$ & $7.62 \pm 3.46$ & $4.26 \pm 4.25$ \\
\hline
\end{tabular}


Table 2 Matrix of Correlation Coefficients between Health Practice Index (HPI), The 28-items General Health Questionnaire (GHO) and the Other Psychosocial Factors in the Age Group 20-29

*Correlation Coefficients ( $99 \%$ Confidence Interval) $(n=639)$

\begin{tabular}{|c|c|c|c|c|c|}
\hline Items & $\begin{array}{c}\text { The } 28 \text {-items } \\
\text { GHQ }\end{array}$ & $\begin{array}{l}\text { Work-Life } \\
\text { Satisfaction }\end{array}$ & $\begin{array}{c}\text { Life } \\
\text { Satisfaction }\end{array}$ & $\begin{array}{l}\text { Social } \\
\text { Support }\end{array}$ & $\begin{array}{l}\text { Number of } \\
\text { Night Shift }\end{array}$ \\
\hline$\cdot$ HPI & $\begin{array}{c}-0.29 * * \\
(-0.38 \sim-0.19)\end{array}$ & $\begin{array}{c}-0.24^{* *} \\
(0.14 \sim 0.33)\end{array}$ & $\begin{array}{c}0.24^{* *} \\
(0.14 \sim 0.33)\end{array}$ & $\begin{array}{c}0.03 \\
(-0.07 \sim 0.13)\end{array}$ & $\begin{array}{c}-0.02 \\
(-0.12 \sim 0.08)\end{array}$ \\
\hline $\begin{array}{l}\text { - The } 28 \text {-items } \\
\text { GHQ }\end{array}$ & & $\begin{array}{c}-0.44^{* *} \\
(-0.52 \sim-0.35)\end{array}$ & $\begin{array}{c}-0.42^{* *} \\
(-0.50 \sim-0.33)\end{array}$ & $\begin{array}{c}-0.16^{* *} \\
(-0.26 \sim-0.06)\end{array}$ & $\begin{array}{c}0.11^{*} \\
(0.01 \sim 0.21)\end{array}$ \\
\hline $\begin{array}{l}\cdot \text { Work-Life } \\
\text { Satisfaction }\end{array}$ & & & $\begin{array}{c}0.42^{* *} \\
(0.33 \sim 0.50)\end{array}$ & $\begin{array}{c}0.16^{* *} \\
(0.06 \sim 0.26)\end{array}$ & $\begin{array}{c}-0.15^{* *} \\
(-0.25 \sim-0.05)\end{array}$ \\
\hline $\begin{array}{l}\cdot \text { Life } \\
\text { Satisfaction }\end{array}$ & & & & $\begin{array}{c}0.16^{*} \\
(0.06 \sim 0.26)\end{array}$ & $\begin{array}{c}-0.12^{* *} \\
(-0.22 \sim-0.02)\end{array}$ \\
\hline $\begin{array}{l}\text {-Social } \\
\text { Support }\end{array}$ & & & & & $\begin{array}{c}0.03 \\
(-0.07 \sim 0.13) \\
\end{array}$ \\
\hline
\end{tabular}

示していた $(\mathrm{p}<0.001)$ 。働きがい度と生活満 足度は正の有意な相関を示していた $(\mathrm{p}<0.001)$ 。 GHQは働きがい度, 生活満足度, 社会的支援 $(\mathrm{p}<0.001)$ と負の相関を有意に示していた。 GHQは夜勤回数と正の有意な相関 $(\mathrm{p}<0.01)$ を 示していたが, 相関係数は 0.09 と 0 に近い值を 示した。生活満足度は社会的支援と正の相関 $(\mathrm{p}<0.01)$ を有意に示していたが，相関係数は 同様に0.09とあまり高い值ではなかった。夜勤 回数と働きがい度, 生活満足度は負の有意な相 関 $(\mathrm{p}<0.001)$ をしていた。図 1 はその結果 を示したものである。全対象者の結果は今回は
図表に示していないが，20歳代の対象者は639 人で全体の $55.5 \%$ を占めるため, 20 歳代と相関 係数の結果が同様の傾向であった。表 3 に30歳 代の相関行列と図 2 にその結果を示した。GHQ はHPI, 働きがい度, 生活満足度, 社会的支援 に有意 $(\mathrm{p}<0.001)$ な負の相関を示していた。HPI は働きがい度および生活満足度と, 働きがい度 は生活満足度および社会的支援に有意 $(\mathrm{p}<0.001)$ な正の相関を示していた。30歳代では夜勤回数 については関連は認められなかった。表 4 は40 歳代の相関行列, 図 3 はその図を示した。GHQ とHPI, 働さがい度, 生活満足度, 社会的支援

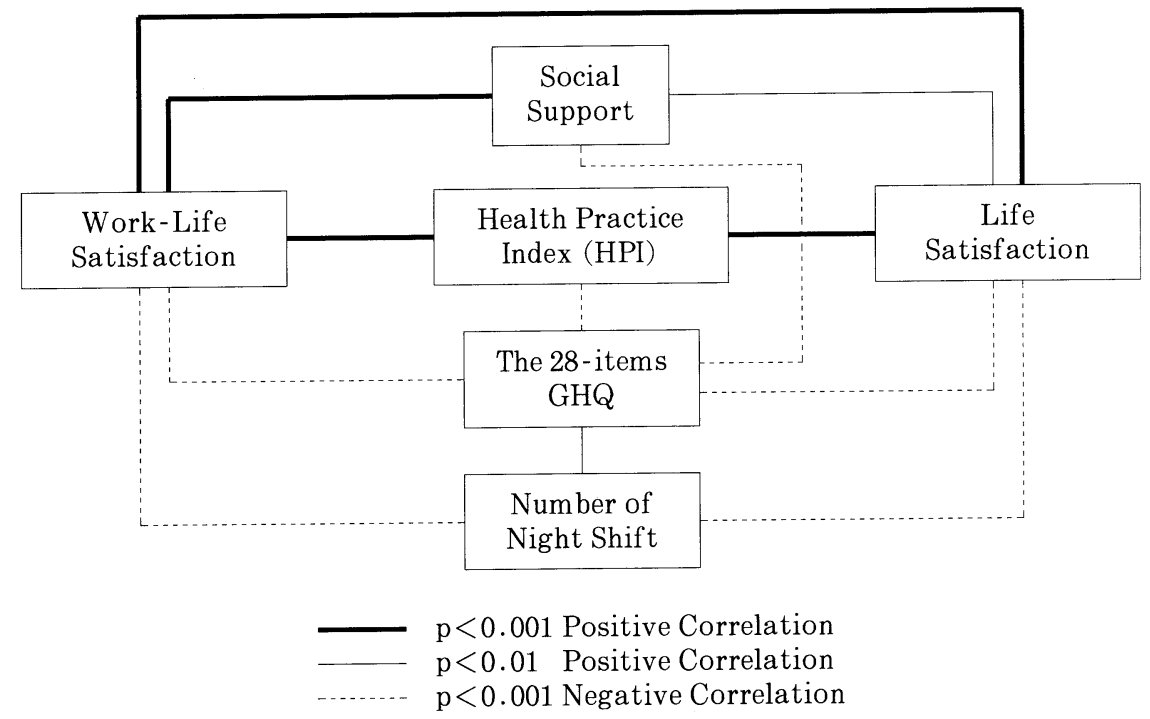

Fig. 1 Correlation Coefficients with between Health Practice Index (HPI), and the Other Psychosocial Factors in the Age Group 20-29 
Table 3 Matrix of Correlation Coefficients between Health Practice Index (HPI), The 28-items General Health Questionnaire (GHQ) and the Other Psychosocial Factors in the Age Group 30-39

*Correlation Coefficients (99\% Confidence Interval) $(n=308)$

\begin{tabular}{|c|c|c|c|c|c|}
\hline Items & $\begin{array}{c}\text { The } 28 \text {-items } \\
\text { GHQ }\end{array}$ & $\begin{array}{c}\text { Work-Life } \\
\text { Satisfaction }\end{array}$ & $\begin{array}{c}\text { Life } \\
\text { Satisfaction }\end{array}$ & $\begin{array}{c}\text { Social } \\
\text { Support }\end{array}$ & $\begin{array}{l}\text { Number of } \\
\text { Night Shift }\end{array}$ \\
\hline$\cdot \mathrm{HPI}$ & $\begin{array}{c}-0.29 * * \\
(-0.41 \sim-0.14)\end{array}$ & $\begin{array}{c}0.22^{* *} \\
(0.07 \sim 0.35)\end{array}$ & $\begin{array}{c}0.26^{* *} \\
(0.11 \sim 0.39)\end{array}$ & $\begin{array}{c}-0.01 \\
(-0.15 \sim 0.13)\end{array}$ & $\begin{array}{c}-0.03 \\
(-0.17 \sim 0.12)\end{array}$ \\
\hline $\begin{array}{l}\text { - The } 28 \text {-items } \\
\text { GHQ }\end{array}$ & & $\begin{array}{c}-0.32^{* *} \\
(-0.45 \sim-0.18)\end{array}$ & $\begin{array}{c}-0.37 * * \\
(-0.49 \sim-0.24)\end{array}$ & $\begin{array}{c}-0.28 * * \\
(-0.41 \sim-0.14)\end{array}$ & $\begin{array}{c}0.05 \\
(-0.10 \sim 0.20)\end{array}$ \\
\hline $\begin{array}{l}\text {-Work-Life } \\
\text { Satisfaction }\end{array}$ & & & $\begin{array}{c}0.38^{* *} \\
(0.24 \sim 0.50)\end{array}$ & $\begin{array}{c}0.15^{* *} \\
(0.01 \sim 0.29)\end{array}$ & $\begin{array}{c}-0.03 \\
(-0.18 \sim-0.12)\end{array}$ \\
\hline $\begin{array}{l}\cdot \text { Life } \\
\text { Satisfaction }\end{array}$ & & & & $\begin{array}{c}0.03 \\
(-0.12 \sim 0.18)\end{array}$ & $\begin{array}{c}-0.09 \\
(-0.23 \sim 0.06)\end{array}$ \\
\hline $\begin{array}{l}\text {-Social } \\
\text { Support }\end{array}$ & & & & & $\begin{array}{c}0.01 \\
(-0.14 \sim 0.16)\end{array}$ \\
\hline
\end{tabular}
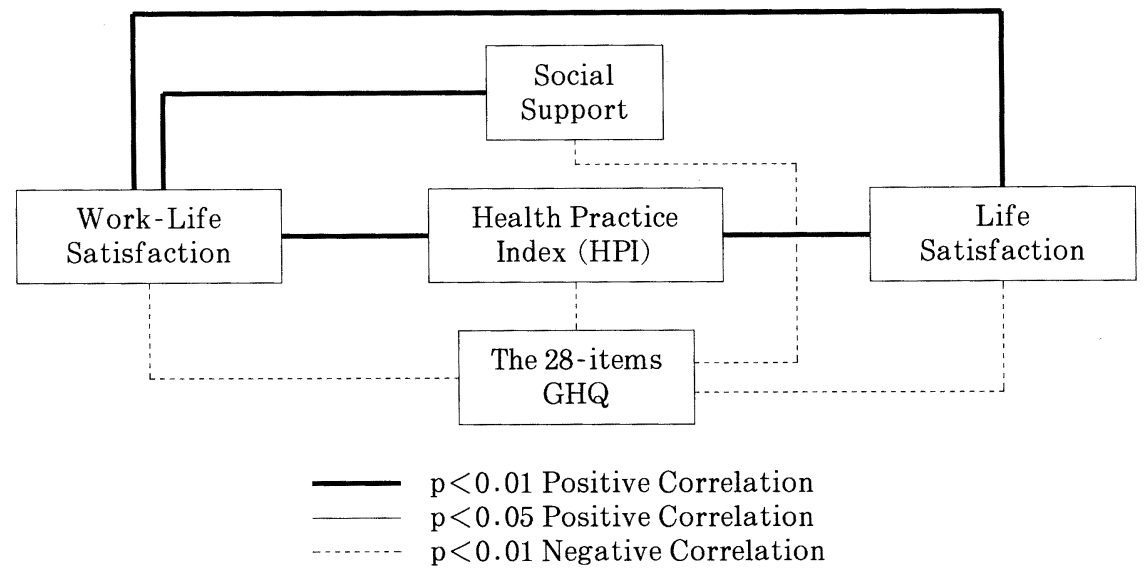

Fig. 2 Correlation Coefficients with between Health Practice Index (HPI), and the Other Psychosocial Factors in the Age Group 30-39

Table 4 Matrix of Correlation Coefficients between Health Practice Index (HPI), The 28-items General Health Questionnaire (GHQ) and the Other Psychosocial Factors in the Age Group 40-49

*Correlation Coefficients (99\% Confidence Interval) $(n=161)$

\begin{tabular}{|c|c|c|c|c|c|}
\hline Items & $\begin{array}{c}\text { The } 28 \text {-items } \\
\text { GHQ }\end{array}$ & $\begin{array}{l}\text { Work-Life } \\
\text { Satisfaction }\end{array}$ & $\begin{array}{c}\text { Life } \\
\text { Satisfaction }\end{array}$ & $\begin{array}{c}\text { Social } \\
\text { Support }\end{array}$ & $\begin{array}{l}\text { Number of } \\
\text { Night Shift }\end{array}$ \\
\hline •HPI & $\begin{array}{c}-0.20^{*} \\
(-0.34 \sim-0.05)\end{array}$ & $\begin{array}{c}0.14 \\
(-0.02 \sim 0.29)\end{array}$ & $\begin{array}{c}0.12 \\
(-0.04 \sim 0.27)\end{array}$ & $\begin{array}{c}0.01 \\
(-0.15 \sim 0.16)\end{array}$ & $\begin{array}{c}0.07 \\
(-0.09 \sim 0.22)\end{array}$ \\
\hline $\begin{array}{l}\text { - The } 28 \text {-items } \\
\text { GHQ }\end{array}$ & & $\begin{array}{c}-0.40^{* * *} \\
(-0.52 \sim-0.26)\end{array}$ & $\begin{array}{c}-0.50^{* * *} \\
(-0.61 \sim-0.37)\end{array}$ & $\begin{array}{c}-0.21^{* *} \\
(-0.35 \sim-0.06)\end{array}$ & $\begin{array}{c}0.05 \\
(-0.11 \sim 0.20)\end{array}$ \\
\hline $\begin{array}{l}\text {-Work-Life } \\
\text { Satisfaction }\end{array}$ & & & $\begin{array}{c}0.42^{* * *} \\
(0.28 \sim 0.54)\end{array}$ & $\begin{array}{c}0.28^{* * *} \\
(0.13 \sim 0.42)\end{array}$ & $\begin{array}{c}-0.13 \\
(-0.28 \sim 0.03)\end{array}$ \\
\hline $\begin{array}{l}\text { - Life } \\
\text { Satisfaction }\end{array}$ & & & & $\begin{array}{c}0.21^{* *} \\
(0.06 \sim 0.35)\end{array}$ & $\begin{array}{c}-0.09 \\
(-0.24 \sim-0.07)\end{array}$ \\
\hline $\begin{array}{l}\text {-Social } \\
\text { Support }\end{array}$ & & & & & $\begin{array}{c}0.02 \\
(-0.14 \sim 0.17)\end{array}$ \\
\hline & & & $\uparrow p<$ & $* * p<0.001$ & $* * * \mathrm{p}<0.001$ \\
\hline
\end{tabular}




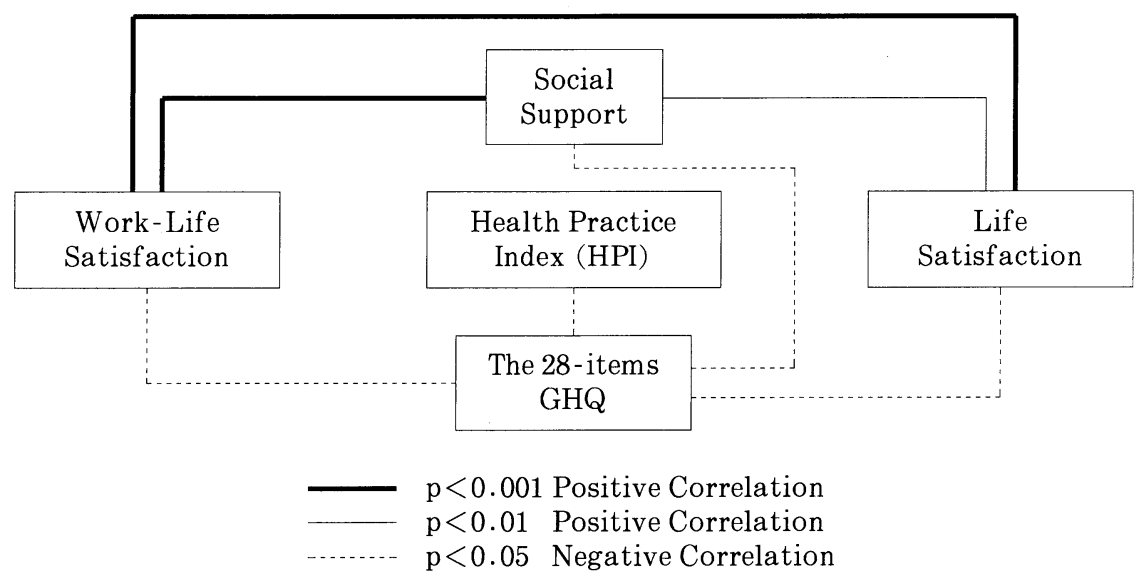

Fig. 3 Correlation Coefficients with between Health Practice Index (HPI), and the Other Psychosocial Factors in the Age Group 40-49

と有意 $(\mathrm{p}<0.05)$ に負の相関を示していた。働 きがい度と生活満足度, 社会的支援と生活満足 度, 働さがい度が有意 $(\mathrm{p}<0.05)$ な正の相関を 示していた。表 5 は50歳代の相関行列, 図 4 は その図を示した。GHQと働きがい度および生 活満足度と有意 $(\mathrm{p}<0.05)$ な負の相関を示して いた。社会的支援とHPI, 働きがい度, 生活満 足度が有意 $(\mathrm{p}<0.05)$ に正の相関を示していた。

\section{IV. 考察}

看護婦は極めて不規則な勤務体制を行ってい る上に他職種と比べ作業量も多く, そのため慢 性的な疲労も蓄積し易いと言われている1)。本 研究は，不規則な勤務体制にある看護婦のライ フスタイルの現状とその心理社会的要因との関
連についてに着目した。ライフスタイルに関す る研究は森本ら ${ }^{5 \sim 8)}$ を中心に進められている が，看護婦など不規則な勤務体制を有する職種 についての検討はまだ少ない。

ライフスタイル得点であるHPIについては, 一般労働者の報告では女性の得点は5.13 , 男 性4.13より高かく8), 女性のライフスタイルの 方が良い傾向にあった。しかし, 本研究の看護 婦の得点は $4.78 \pm 1.29$ と平均得点としてはその 中間を位置していた。看護婦は他の女性の職種 と比べ, 労働上の負担などが大きく, 一般労働 者の女性に比べ，健全なライフスタイルを保持 するのに難しい状況であることが推察される。

働きがい度は, 労働生活の質 “Quality of Working Life”を計るための尺度で, 労㗢生

Table 5 Matrix of Correlation Coefficients between Health Practice Index (HPI), The 28-items General Health Questionnaire (GHO) and the Other Psychosocial Factors in the Age Group 50 or over *Correlation Coefficients (99\% Confidence Interval) $(n=42)$

\begin{tabular}{|c|c|c|c|c|c|}
\hline Items & $\begin{array}{c}\text { The } 28 \text {-items } \\
\text { GHQ }\end{array}$ & $\begin{array}{l}\text { Work-Life } \\
\text { Satisfaction }\end{array}$ & $\begin{array}{c}\text { Life } \\
\text { Satisfaction }\end{array}$ & $\begin{array}{c}\text { Social } \\
\text { Support }\end{array}$ & $\begin{array}{l}\text { Number of } \\
\text { Night Shift }\end{array}$ \\
\hline$\cdot \mathrm{HPI}$ & $\begin{array}{c}-0.20 \\
(-0.47 \sim 0.11)\end{array}$ & $\begin{array}{c}0.13 \\
(-0.18 \sim 0.41)\end{array}$ & $\begin{array}{c}0.14 \\
(-0.17 \sim 0.42)\end{array}$ & $\begin{array}{c}0.44^{* *} \\
(0.16 \sim 0.66)\end{array}$ & $\begin{array}{c}-0.01 \\
(-0.31 \sim 0.29)\end{array}$ \\
\hline $\begin{array}{l}\text { - The } 28 \text {-items } \\
\text { GHQ }\end{array}$ & & $\begin{array}{c}-0.32^{*} \\
(-0.57 \sim-0.02)\end{array}$ & $\begin{array}{c}-0.38^{*} \\
(-0.61 \sim-0.09)\end{array}$ & $\begin{array}{c}-0.21 \\
(-0.48 \sim 0.10)\end{array}$ & $\begin{array}{c}0.02 \\
(-0.29 \sim 0.32)\end{array}$ \\
\hline $\begin{array}{l}\text {-Work-Life } \\
\text { Satisfaction }\end{array}$ & & & $\begin{array}{c}0.66^{* * *} \\
(0.45 \sim 0.80)\end{array}$ & $\begin{array}{c}0.43^{* *} \\
(0.15 \sim 0.65)\end{array}$ & $\begin{array}{c}-0.19 \\
(-0.47 \sim 0.12)\end{array}$ \\
\hline $\begin{array}{l}- \text { Life } \\
\text { Satisfaction }\end{array}$ & & & & $\begin{array}{c}0.29 * \\
(-0.02 \sim 0.55)\end{array}$ & $\begin{array}{c}-0.28 \\
(-0.53 \sim 0.03)\end{array}$ \\
\hline $\begin{array}{l}\text {-Social } \\
\text { Support }\end{array}$ & & & & & $\begin{array}{c}0.24 \\
(-0.07 \sim 0.51) \\
\end{array}$ \\
\hline & & & $\tau p$ & $* * p<0.01$ & $* * * p<0.001$ \\
\hline
\end{tabular}




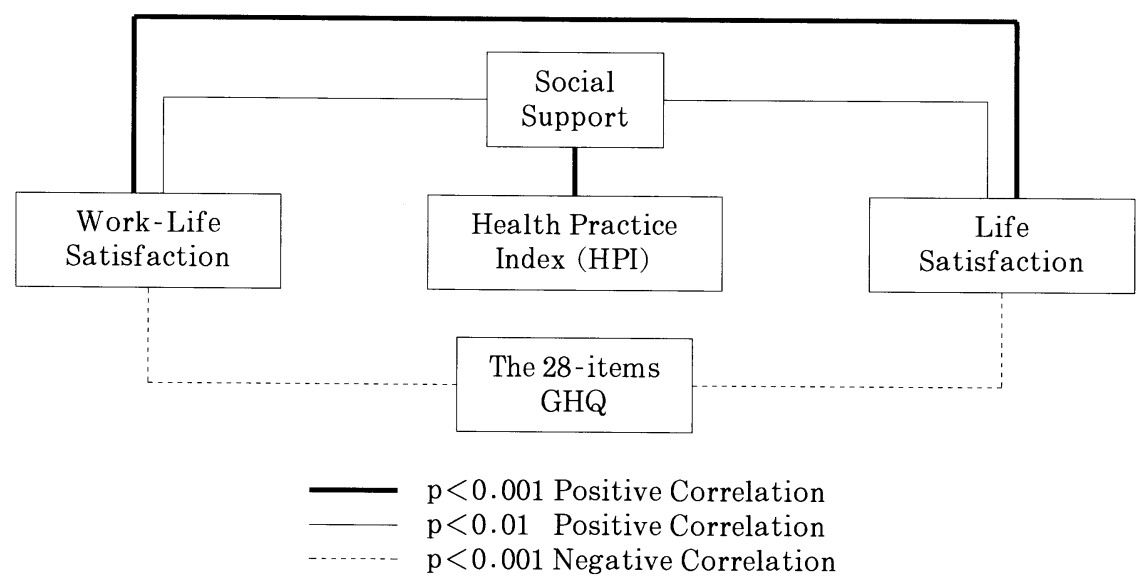

Fig. 4 Correlation Coefficients with between Health Practice Index (HPI), and the Other Psychosocial Factors in the Age Group 50 or over

活の満足度を職場と家庭および余㗇などの要素 による包括的な概念で捉えている。わが国では 尾崎ら ${ }^{16)}$ がわが国の看護婦の仕事への満足度 について検討している。尾崎は看護の職の仕事 の満足度を計るために，Stamps ${ }^{17)}$ の尺度を用 いている。本研究では他種職との比較などの目

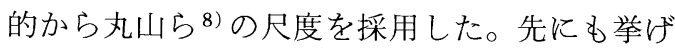
た一般事業所の㗢さがい度の平均については男 性 9.38 点, 女性 10.03 点であり, 本研究の看護 婦が $6.49 \pm 2.74$ と低い傾向にあった。これにつ いては看護職として特有な交代勤務によるスト レスの蓄積, 家族や友人との交流の時間の減少, 労働環境の不備や医療現場における人間関係の 複雑さなどによる影響が考えられる。他職種の 比較して良好でない状況を示していることから も, 今後さらに改善を進めるよらに検討する必 要性が示唆されたと言える。

本調査の全対象者におけるHPI と社会心理的 要因との相関についでは，ライフスタイルが働 きがい度, 生活満足度, 精神健康度之有意に比 較的強い相関を示していた。丸山ら ${ }^{8)}$ の研究で は健康に関しては精神健康度ではなく，不定愁 訴について検討しているが，㟫涪同様の結果で あり, 看護婦のライフスタイルに関わる要因は, 一般労働者とほぼ同様の傾向であることが分かっ た。

看護婦は常に看護業務上生死に関わる多様な ストレスに曝されている。20歳代は, 臨床経験 は十分でないのに夜勤などの回数も最も多く,
臨床の最先端の場面で勤務することがほとんど である。一方，30歳代，40歳代，50歳代では, 経験が豊かになり臨床看護における実践能力も 培われている。年代が進むにつれ管理職につき, スーパーバイザーとしての采配も問われ，管理 職としての新たなストレスが加わるであろら。 また，女性としてのライフサイクルなど，看護 婦の各年齢代において，それの特徵な問題が潜 んでおり，それらが本研究で検討するライフス タイルや心理社会的要因にも影響を与えている と考え，20歳代から50歳代の4つのグループに 分けて検討した。

20歳代の看護婦は，ライフスタイルおよび精 神健康度について最も良好でない状況を示して した。特に，ライフスタイルは，働きがい感， 生活満足度, 精神健康度と有意に関連している。 しかし，夜勤回数が最も多いこと，あるいは表 には示さなかったが 1 人暮らしの割合が他の年 齢層では1割程度であるのに対して，20歳代で は21.8\%と最も多く，理想的なライフスタイル を実践するのが非常に難しい現状が明らかになっ たと言える。

精神健康度については, 福西 ${ }^{18)}$ のCut-off point が6/7点であることや, 椎谷ら ${ }^{19)}$ の調査の調査 に比べ, 本研究の対象者においては精神健康度 が良好でない傾向を示していた。永田ら20)の 大学病院の 20 歳代の看護婦の結果でもGHQの 高得点の割合が高い傾向を示しており，対象者 の偏りによる影響が考えられる。本対象者が公・ 
私立の 100 床以上の病院勤務の常勤の看護婦を 対象としたことから，勤務状況ではその活とん どが夜勤勤務体制を取っており，睡眠障害ある いは不安, 抑徒といったストレス状態にある人 を多く含む傾向があったに違いない。しかしな がら，これらの精神健康度の高い原因を明らか にし，改善策を検討するためには，さらに詳し い解析を進める必要がある。また, 年齢階級で GHQが高かったのは20歳, 30歳代であること から, 経験の浅い年代層にとって看護業務は非 常にストレスであり, 精神面での問題には注意 する必要があるだろう。20歳代においては, 夜 勤回数が精神健康度, 働きがい度や生活満足度 と有意な相関を示していた。これはこの年齢層 が最も多くの夜勤勤務をしていることから, 夜 勤回数による睡眠障害やそれによる身体の不調 などが影響していると考えられる。20歳代のこ れらの結果から, 夜勤による疲労感は精神健康 度を悪化させたり, 働きがい感や満足度などの 看護婦のQOLに関連する要因を低下させるこ とが示唆されと言えよう。しかし，この様な状 況にあっても社会的支援などの職場の人間関係 を良好にしていくことにより, 精神的ストレス が改善されることも推察される。

30歳代については，20歳代に比べて夜勤回数 も少なく, 夜勤回数に関する他の要因への影響 は否定されたが，ライフスタイルについては20 歳代と同栐な傾向が認められた。20歳代および 30 歳代の精神的な健康度を良好に保つ対策とし て, 働きがい感を高めるための環境改善と同様 に，ライフスタイルの適正化としての食生活お よスポーツの推進など生活指導などの必要性が 示唆されたと言える。

40歳代の特徵としては, HPI と有意な関連が 認められたのはGHQのみであるが，一方， GHQ は他の 4 つの要因すべてに対しても有意に関連 性を示している。この結果からは, ライフスタ イルよりも, この年代層は $\mathrm{GHQ}$ と他要因の関 連の影響が大さいことが認められる。また, 反 対にライフスタイルの影響する要因の最も少な い年代とも言えるが, HPIは年齢層が進むに従 い良好な状況を示している。40歳代においてラ イフスタイルがこれら要因の中心ではなくとも,
健康的な理想的なライフタイルは 20 歳代, 30 歳 代よりも維持されているのであろう。

50歳代ではHPI と社会的支援に正の相関が認 められたことは，他の年齢層に比へ，管理者お よび既婚者の占める割合が多いことが原因の一 つとして考えられる。看護者として直接的なケ アを実践するよりも人間関係を調節する立場で あったり，また，家の中においても子供や老親 の問題などさらに複雑な対人関係の問題が浮上 する時期である。対象者が最も少ないことから も，50代の常勤の勤務を継続させることは難し いことが考えられる。ライフスタイルと社会的 支援が関連していことは，他の年齢層では認め られない大きな特徵であろう。現在勤務してい る年代層においては, 他の年齢層に比べ, 人間 関係を生活上の重要な位置づけに拈いていると 考兄られる。HPI も他の年齢層に比べ最も高い 得点を示して括り, 他の要因では影響の受けに くく，個人において確立された理想的なライフ スタイルを保持している人が多いことも伺われ た。

看護婦は女性の代表的な職業のひとつでもあ り, 結婚, 出産などで一端離職しても再就職す る割合は他職種より高い傾向にあると言われて いる21)。これは一つに看護婦の職務に対する 意識は, 本研究で検討した一般的な働きがい感 よりも, Stampsら ${ }^{17)}$ が問題としている看護職 務に関わる満足度の占める割合が高いためとも 考えられる。しかしながら，看護婦の働きがい 度が他職種に比べ低いという現状は, 夜勤など の労働条件などを始め看護業務において, 今後 も改善の必要性があることを示唆していると言 えよう。また，各年齢層におけるライフスタイ ルと働さがい度などの特徵も明らかにされ, 特 に, 20歳代, 30歳代では相互の関連が認められ たことから，看護管理においてもライフスタイ ルに関するアプローチが必要であることが結果 から推察された。

先に述べたが, 対象者の偏りといら点で問題 も残る。対象集団の選択の段階において, 今後 はできるたけ偏りがない方法をとる必要がある。 今後はさらに残された課題を検討を深めるため に，解析，検討を継続するつもりである。 


\section{謝辞}

今回の調査に関しまして，多大なご協力を頂 きました各病院の皆様方に深く感謝致します。

\section{文献}

1 ）久繁哲徳, 他：病院看護婦の疲労と健康状 態について一第 1 編看護婦の疲労と健康状 態の比較, 労働科学, 61(11), 517-528, 1985.

2 ) 稲岡文昭, 川野雅資 : 看護職のBurn-out と社会的環境および行動特性との関連につ いての研究——般医, 精神科医との比較を 通して一, 看護科学学会誌, 6(3), 50-60, 1986 .

3 ）影山隆之, 他：病院勤務看護職者の精神衛 生. 産業医学, 33, 31-44, 1991.

4 ) 藤田和夫 : 看護婦の心身健康に関する問題, 日本看護協会調査研究報告, 27, 11-88, 1988.

5 ) 森本兼囊：ライフスタイルと健康度との関 連性に関する予防医学的研究, 平成 3 年度 科学研究費助成金研究結果報告書, 1993.

6 ) 森本兼囊：健康意識之健康志向行動, ライ フスタイルと健康, 医学書院, 東京, 53-52, 1991.

7 ）森本兼囊：ライフスタイルと健康, 身体的 健康度と精神的健康度, 公衆衛生, 51(2), 135-143, 1987.

8 ）丸山宗一朗, 森本兼虽他：労働者の働きが い感之健康習慣・自覚症状との関連性. 日 本衛生学誌, 45(6), 1082-1094, 1991.

9 ) 武田文 : ホワイトカラー男子勤務者の年齢 層別にみた労働生活と健康状況一労働生活 とライフスタイルー，民族衛生，57(6)，227238, 1991 .

10) Belloc NB, Breslow L: Realtionship of Phys- ical Health Status and Health Practice. Preventive Medicine, 1(3) , 409-421, 1972.

11) Berkman LF and Breslow L: Health and Way of Living. Oxford University Press, N.Y., 1983.

12) Goldberg DP and Hillier VF: A Scaled Version of the General Health Questionnaire. Psychological Medicine, 9, 39-145, 1979.

13）中川泰杉：日本語版GHQ精神健康調查票 手引, 日本文化科学社, 1995 .

14）杉澤秀博, 他：要介護老人の介護者におけ る主観的健康観および生活満足感の变化と その関連要因に関する研究. 日本公衆衛生 雑誌, 39(1)，23-32，1992.

15) Linn, LS., et al.: Health Status, Job Satisfaction, Job Stress and Life satisfaction among Academic and Clinical Faculty, JAMA, 254, 2775-2782, 1985. 138, 1991.

16）尾崎フサ子 : 看護婦の仕事への満足度に関 する研究, 看護研究, 20(3), 302-311, 1987.

17) Stamps, P.L., et al.: Measuremnt of work satisfaction among health professionals, Medical Care, 16(4), 337-352, 1978.

18）福西勇夫：日本語版General Health Questionnaire (GHQ) のcut-off point, 心理臨床, 3(3), 228-234.

19）椎谷淳二, 宗像恒次, 他：精神薄弱者施設 職員の精神健康とその社会的背景(第一報) 精神保健研究, 36, 113-121, 1990.

20）永田耕司，他：一般健康質問票調査からみ た保健婦と看護婦のメンタルヘルス，民族 衛生, 59(4), 186-195, 1993.

21）奥村元子：看護職員の移動と定着に関する 意識と実態，看護，43(3), 127-142, 1991. 